\title{
Rivalry of Advocacy Coalitions in the Czech Pension Reform
}

Martin Potůček, Veronika Rudolfová

\begin{abstract}
${ }^{1}$ Abstract
The Czech Republic, as many other countries of Central and Eastern Europe, faced and is still facing a pension-reform challenge. The diversification of pension pillars led to the massive displacements of participant contributions from the public PAYG pension pillars to the newly constructed private, defined-contribution, fully-funded pillars. In the Czech Republic, the adoption of the relevant law was preceded by serious political conflict between supporters and opponents of this step (both among different political actors and among professionals). In an analysis of the conflict we critically apply the Advocacy Coalition Framework. We work mainly with the analysis of policy documents, public statements of the individual actors and an analysis of voting on the relevant law in both chambers of the Czech Parliament towards the identification of the crystallization process of two clear-cut coalitions between actors from both sides of the spectrum. The Advocacy Coalition Framework in exploring the dynamics of the public-policy process proved to be able to explain situations where there is sharp political conflict. Through the lens of the devil-shift of both camps (advocacy coalitions with different beliefs), each fell into extreme positions within the coalition to affirm the correctness of their arguments and positions.
\end{abstract}

\section{Keywords:}

Pension reform, Czech Republic, diversification of the pension system, the Advocacy Coalition Framework, PAYG pension pillar, a defined-contribution fully-funded pension pillar

1 Center for Social and Economic Strategies, Faculty of Social Sciences, Charles University in Prague, Smetanovo nábř. 6, 11000 Praha 1, Czech Republic. potucek@fsv.cuni.cz 


\section{Introduction}

Disputes about pension reform could be a good example of the public-policy process in which opposite forces govern (and arm) opinions of different camps - the advocacy coalition. The key attributes of the external struggle are, according to the Advocacy Coalition Framework, the differences of viewpoints (ideologically conditioned) of the individual participants. Behind them, however, we can sense a number of differentiated interests (though often obscured behind the "veil" of ideological beliefs). It is not surprising that this ideologically polarized issue over time has created a coalition of stakeholders from different spheres, brought together by a common vision for this particular reform strategy. With a large degree of simplification, camps can be defined through the optics of right-left political ideologies, connected to and emphasizing their values as reflected in pension policy. On the right side of the political spectrum, the values which resonate are the ones associated with the emphasis on the regulatory role of the market and individual responsibility, which governs the areas of strengthening the degree of equivalence in the pension system (the more you contribute now, the more you will get back later on) and the increasing role of commercial entities in ensuring seniors. On the left side of the political spectrum, the value of solidarity in the pension field associated with the role of public authorities and institutions, the first pillar of the pension system, is stressed. This simplification has its exceptions, of course. For example, in the Czech Republic, the right-wing parties reduced the degree of equivalence of the publicpension pillar with the aim of reducing its role in the whole pension system at the beginning of the 1990s. Nevertheless, they strengthen the degree of equivalence of the public-pension pillar, following the ruling of the Constitutional Court in 2011.

If this ideological and political struggle in the case of such an important longterm cyclical system, such as the pension system, does not result in a political compromise and agreement, the likelihood that the adopted solution will not be sustainable is increased. This happened in the case of the second pillar of the Czech pension system.

\section{The advocacy coalition framework}

The Advocacy Coalition Framework (hereafter ACF) is an influential theory of the process of public-policy creation, which is based on the idea that interest groups are organized in policy communities within the policy domain (Birkland 2005, 226).

The ACF scheme (based on Sabatier and Weible 2007) shows a subsystem of public policies with coalitions, their sources and beliefs and the outputs and outcomes of public policies. The subsystem is anchored in the broader political system with relatively stable parameters and external events (dynamic element). 


\section{Diagram}

The Advocacy Coalition Framework

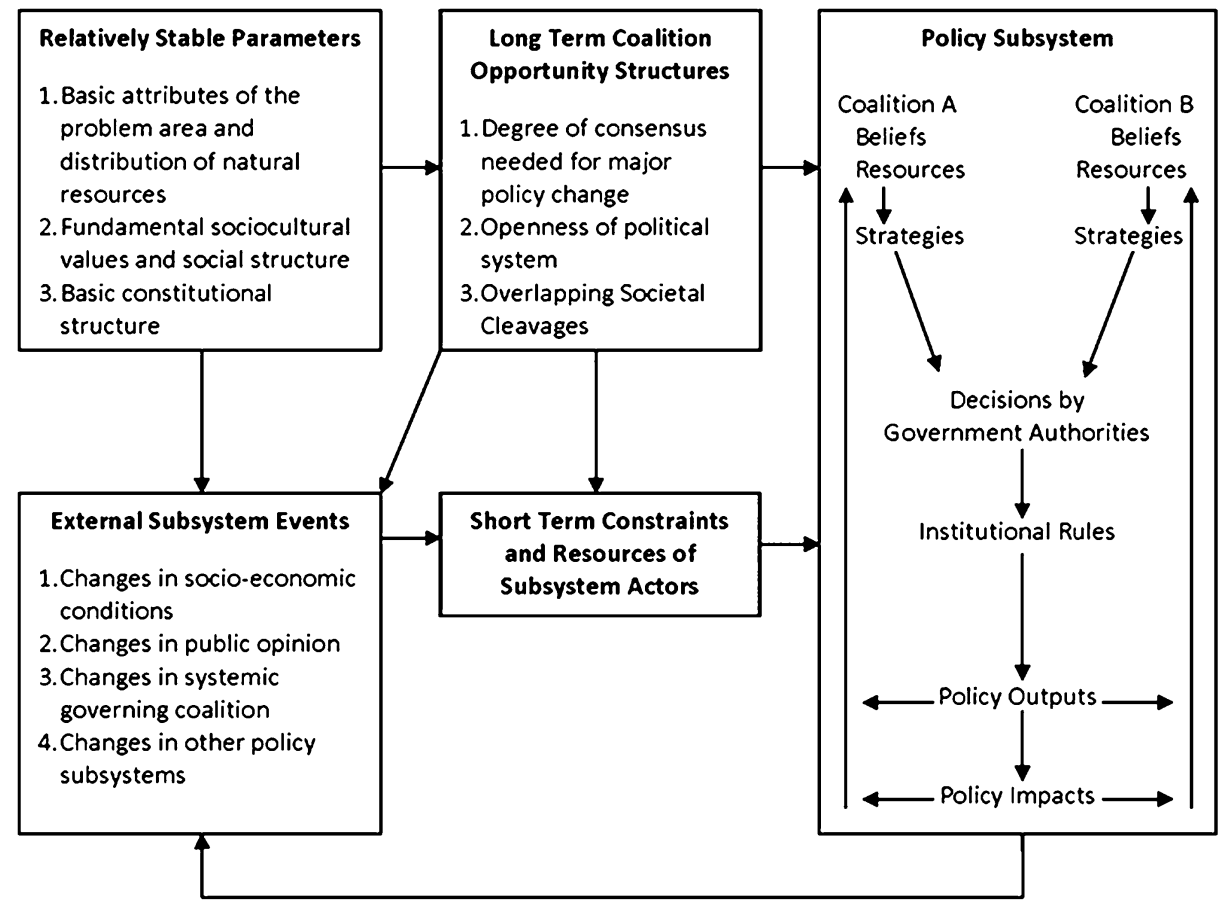

Source: Weible et al. $(2011,352)$, Weible and Nohrstedt $(2013,128)$.

ACF works with the social-psychological model of the individual, which is different from the model of the rational individual used by the public-choice theory. The key element of the concept is the existence of belief systems. ACF perceives core beliefs and values as the main driving force of political behavior, i.e. the dealings of actors. Another ACF assumption is the so-called aversion of an individual to losses - a prospective theory (Quattrone and Tversky 1998). We simply tend to remember our losses more than our gains.

Advocacy coalitions are defined as a group of actors who share basic beliefs about the public policy (policy core beliefs) and coordinate their actions. Advocacy coalitions form a dynamic environment in which the actors belonging to the coalition may vary according to their beliefs and attitudes toward current public-policy issues. 
Advocacy coalitions have different resources and tools to achieve their goals:

1) access to formal authority that has the right to make political decisions (legislators, judges), or directly to the membership of such an actor in the coalition (e.g. political parties in power);

2) public opinion and public support;

3) information, knowledge;

4) mobilizing sympathizers and supporters;

5) funds;

6) the presence of charismatic leaders (Kingdon 1994; Mintrom and Vergari 1996).

Due to the nature of advocacy coalitions, a radical change inside the subsystem is extremely unlikely. ACF therefore defines external direct or indirect shocks as agents of change.

\section{Analysis - Commencement and termination of fully-funded, defined-contribution "second pillar" using ACF}

In the following, we will analyze the behavior and development of two advocacy coalitions (hereinafter: AC). One AC promotes the introduction of the private, defined-contribution, fully-funded pillar (shortly: second pillar) to the Czech pension system. Another AC holds the opposite opinion, i.e. it is opposed to the introduction of the second pillar to the Czech pension system.

\subsection{Formation of advocacy coalition - the introduction of a second pillar}

The formation of the advocacy coalition, supporting the introduction of a second pillar in the Czech pension system, started slowly with attempts to convince experts as well as the general public of the fiscal unsustainability of the public, definedbenefit, pay-as-you-go (PAYG) public pension system (shortly: first pillar) due to the aging population. This topic has been present in the discussions since 1995, but it received top attention and political support at the dawn of the new Millennium.

Under the caretaker government (before early election in 2010), the Expert Advisory Corps (PES) was established in January 2010. Its main objective was to analyze the current state of the pension issue in a broader context and recommend to future governments possible ways of reforming the pension system. The creation of the team was commissioned by Vladimir Bezděk, who had originally worked at the Czech National Bank (CNB) and led another commission, which played an important role in designing the unsuccessful reform of the pension system in 2003.

Vladimír Bezděk got a "carte blanche" to select his associates. He approached this task with offers especially for those professionals who had opinions which were relatively close to his own to participate in the team. A political component 
was not included in PES. Most experts established on the advisory board worked in the commercial sector, some worked with entities that were potential "sellers" of the new product under consideration. Its creation was also suggested in the final PES paper.

The pension reform proposal of the expert advisory group (PES) included Variant I (majority's) and Variant II, called minority's. Variant I counted with the first pillar, which should go to 25 from a $28 \%$ premium rate and should be adjusted according to the reform proposals. The second pillar will be funded from $3 \%$ of the $28 \%$ premium rates plus individual contribution of $2 \%$ of rough salary of the insured individual. Participation will be mandatory for all persons under 40 (as of the year of the start of the reform).

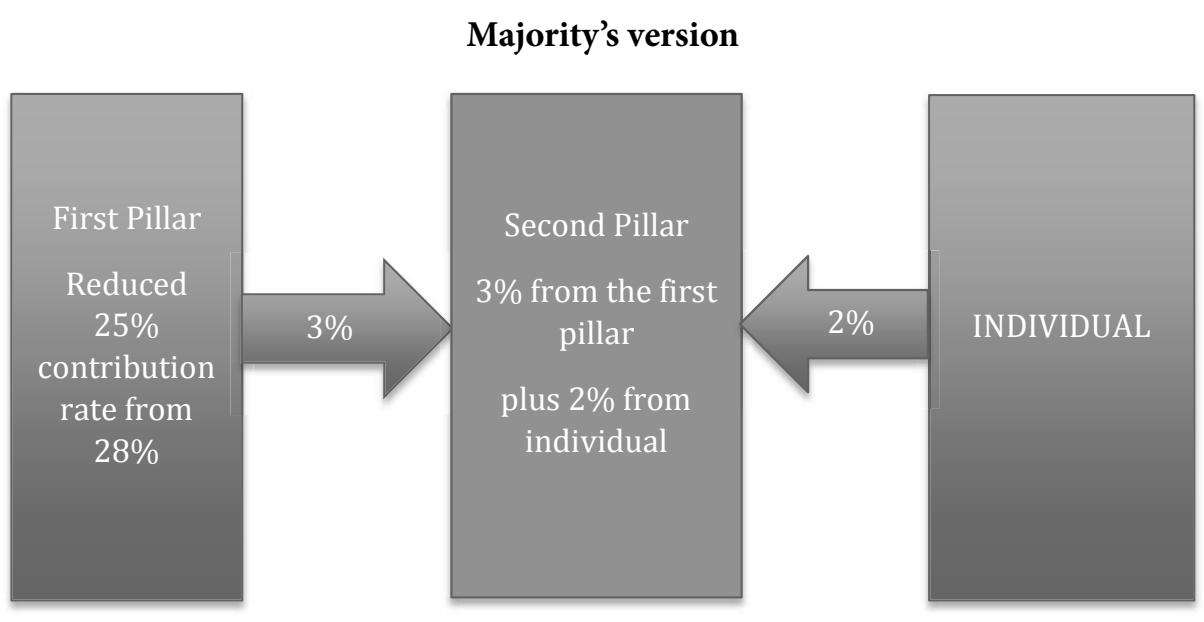

Source: Authors

Variant II involved the following arrangements. The premium rate $(28$ percent) of the first pillar will not change. The second pillar will be operated by the reformed pension funds; direct government support will amount to $3 \%$ of premiums if the participant will save at least the same amount. Entry to the second pillar will be voluntary for those who enter into it, but if they participate, the removal of insurance premiums will be compulsory (MPSV 2010).

Early elections to the Chamber of Deputies of the Czech Parliament, held in 2010, resulted in the formation of a new right-wing coalition government, composed of the Civic Democratic Party (ODS), TOP 09 and Public Affairs (VV). This coalition brought together parties that in the election programs consistently suggested fundamental pension reform, albeit with differences in individual concepts. The government, led by ODS chairman Petr Nečas restored the activities of the National Economic Council (hereinafter NERV). Among the new members were 
Eduard Janota, Minister of Finance from a previous period and Vladimír Bezděk, chairman of the Expert Advisory Group (PES). The experts at NERV were invited to contribute to the preparation of key government reforms, not excluding pensions.

\section{Minority's version}
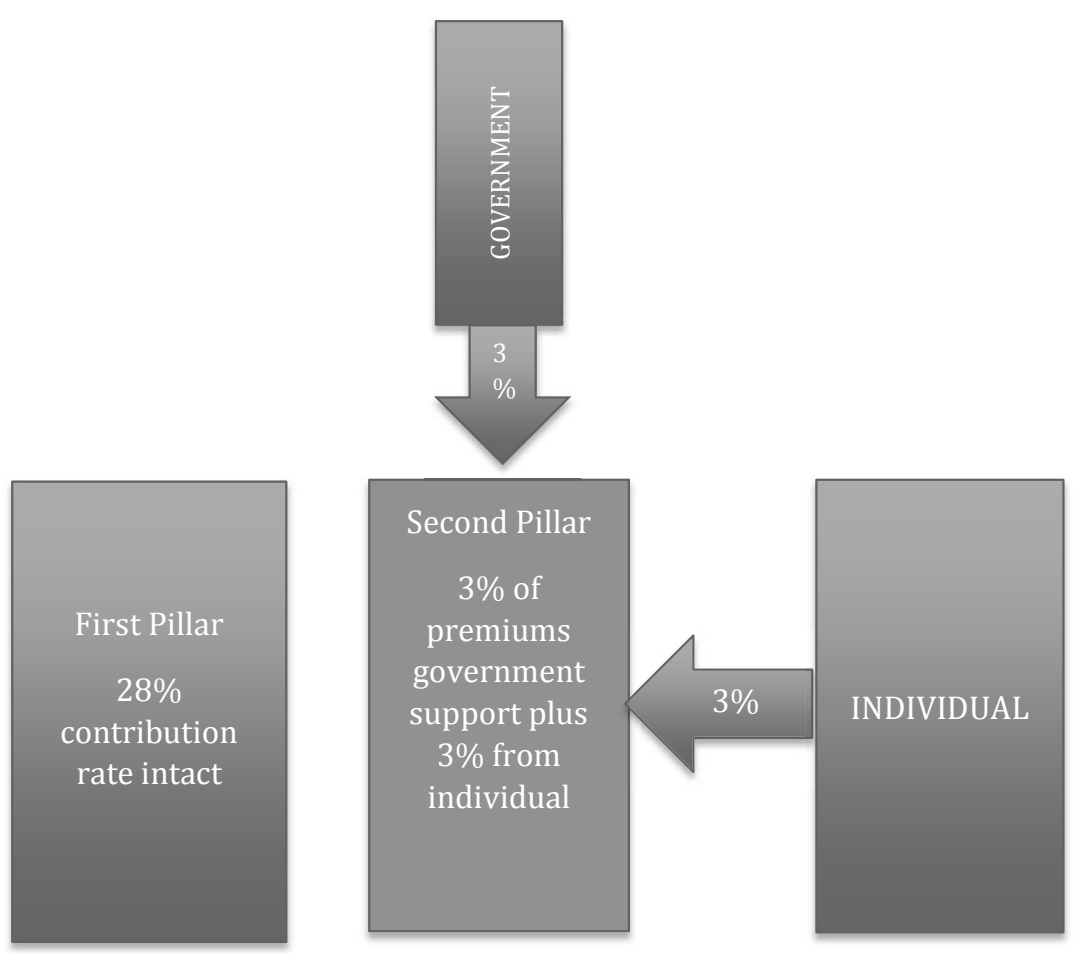

Source: Authors

The activities of NERV followed Variant I of the PES advisory group. The proposed solution was based on arguments about the financial unsustainability of the Czech pension system and promoted the strengthening of the merit system supported by, among other things, the introduction of the second (private, fully-funded, defined-contribution) pillar to the Czech pension system. 
Proposal of NERV from December 2010 included:

$3 \%$ opt-out of the levied $28 \%$ premium rate for continuous public pension insurance.

Premium collection and management would be done by public Social Security Administration.

Investment management would lie on reputable pension funds, investment companies, banks - according to the participant's choice.

Saved funds would be paid in the form of a mandatory annuity.

Opt-out would be mandatory for persons under 40 years of age at the start of the reform. Were they voluntary, opt-out would be utilized by only part of the population, which would make the reforms lose their meaning (NERV 2011).

Other allies in advocacy coalition were potential sellers of new products, e.g. pension savings funds, which would become available upon passage of the pension reforms. A voluntary association of legal entities - The Association of Pension Funds (later renamed the Association of Czech Pension Companies) - which covers institutions operating in the pension market and capital savings (operators of retirement savings, supplementary pension savings and pension) independently participated in the arguments supporting the introduction of the second pillars and additional forms of pension saving, releasing numerous press statements and comments, including the following information campaign on the Internet: "You are getting old. Think."

An umbrella organization united the fragmented arguments of individual entities and thus strengthened its position both within the advocacy coalition and within outside representatives to the advocacy coalition with opposing views. Even after their individual lines individual entities continued to support the elected government's strategy to introduce the second pillar. Financial institutions participated in presentations and workshops articulating the need for the introduction of a second pillar.

Pension companies also participated in the financing and processing academic studies. ČSOB Pension Fund Stability, as an example, engaged the study think tank IDEA in the academic workplace CERGE-EI, which supported the argument which consisted of accentuating the future financial unsustainability of the PAYG pension insurance system (ČSOB 2012).

The result of the joint efforts of actors of this advocacy coalition resulted in the proposal of the governmental pension reform, which allowed for the introduction of the second pillar. However, it was constructed on a voluntary basis, due to the inevitable compromises that were required by the need to sustain the fragile coalition government. 
The governmental proposal included:

Opt-out of $3 \%$ from the $28 \%$ rate levied on insurance premiums plus a mandatory additional $2 \%$ (overall a citizen would thus be burdened with $30 \%$ ).

The selection will be carried out by a single collection point (SCP).

The administration will be carried out by the current reformed pension funds and the newly established pension companies.

Selection in the form of a life annuity, life annuity with survivor's pension for three years, or a 20 years' allowance.

Opt-out is voluntary.

The voluntary nature of the second pillar as proposed by the government would eventually cause profound disagreements between the government and representatives of NERV on what can be accepted as a compromise solution and what already threatens the potential success of pension reforms. Some representatives of NERV distanced themselves from the governmental proposal (Kohout 2011, Tyden.cz 2011). The recommendations for pension reform of NERV were significantly modified by the government, which resulted in the need of NERV to present a deviation from the original idea.

One of the members of NERV, Jiří Rusnok, commented on the government's compromise proposal as follows: "The government reached, after difficult negotiations, this compromise that was only politically acceptable for it but certainly not optimal. I am afraid that under the given conditions many people will not go voluntarily into bringing in money from the continuous system as well as the additional payment. I do not know how they would be motivated by this..." (Adámková 2011).

Dissenting opinions of individual members of NERV are also reflected in the need for the entire advisory board to express their vision of the reform of the pension system and to highlight the differences from the Government of the presented proposal: "Recommendations of the National Economic Council were often distorted and even misinterpreted. ... NERV recommended a number of so-called parametric modifications to the first pillar ... NERV also recommended the introduction of a small but mandatory second pillar where citizens that are under 40 years old would be obliged to save part of their pension. ... The position of the National Economic Council to the pension reform is much more comprehensive, however the above aspects are frequently misinterpreted. Therefore, the listed members of NERV wanted to take this opportunity to set the record straight" (Bezděk et al. 2011).

Although the final decision in the coalition of actors ended in disagreements, the whole process of preparation and formulation of the reform concept linked the same opinions of actors from different areas into a relatively "compact" unit. 
The activity of this advocacy coalition culminated in the approval of Act No. 426/2011, which introduced the second pillar into the Czech pension system.

\subsection{Formation of advocacy coalition - the refusal of the second pillar}

The advocacy coalition at the left side of the political spectrum cemented the opposite opinion. Its members did not believe in the necessity of introducing a second pillar for addressing the issue of pension security. To the participants of the coalition strengthening the equivalence of the system connected to the second pillar meant that the solidarity provided by the public system, especially its limitation, was a core value. At the same time they feared the weakening of the revenue side of the first public PAYG pillar of the pension system without adequate reductions on the expenditure side during the same period.

A key actor in the coalition was the Czech Social Democratic Party (ČSSD). This party announced its comprehensive approach to pension reform at the end of 2011: "Retirement is the most important element of social protection. A key objective of pension reform is to ensure that everyone, present and future pensioners alike, have enough money for a peaceful and dignified life, to maintain an adequate standard of living and the ability to participate in the public, social, economic and cultural life of society. ... Reform must be viewed more broadly, especially in relation to the labor market and population development, which are affected by the pension system retroactively." The program platform also contained an explicit rejection of the creation of an additional fully-funded pillar within the pension system (ČSSD 2011).

One of the important actors was the civic association CESTA - the Centre for Socio-market economy and open democracy (forthwith CESTA), formed in January 2011. This think tank, in December 2011, presented two alternative scenarios of pension reform (a version with a notional defined-contributions pension system similar to the Swedish one, and a version taking into account the care about children in the PAYG system). However, all that united this advocacy coalition was a consistent belief which refused to introduce a second pillar into the Czech pension system; disagreements in this coalition could be found in the detailed ideas about the concepts and alternatives of reform, which are illustrated in the presentation of different reform concepts (CESTA 2011a, 2011b).

A traditional ally of the Social Democrats are unions, represented mainly by the Czech-Moravian Confederation of Trade Unions (ČMKOS). It is therefore not surprising that even the pension policy found that these partners encountered jointly shared beliefs. Regarding pension policy, trade unions are a relatively strong actor in the Czech Republic. In the discussions on pension reform, they protested against the introduction of the second pillar and criticized the government for its reluctance to discuss alternative proposals. In their statements, they criticized the government's proposals in detail and submitted their own concepts. ČMKOS "... rejects the simplistic and one-sided focus regarding pension reform on the financial 
operation of creating a more costly infrastructure in the form of a second private savings scheme" (ČMKOS 2011).

The center-left spectrum is logically complemented by the Communist Party (KSČM), which consistently insisted on only parametric adjustments of the current, PAYG public pillar and opposed the second pillar in the Czech pension system. Opposition to the introduction of the second pillar (i.e. supporting its abolition) was thus evident from the Communist Party, although neither the Social Democrats nor ČMKOS ever received an explicit confirmation of their (KSČM's) opinions. Alternative proposals for pension reform are indeed one of the many weapons used in the political battle for voters on the left side of the political spectrum.

\subsection{The legislative procedure}

The adoption of Act No. 426/2011 Coll. regarding pension savings was preceded by debate in the Chamber of Deputies and then the Senate. The resulting line vote reflected the dispute between advocacy coalitions. Members of advocacy coalitions exclusively on the right side of the political spectrum were advocating the introduction of a second pillar - without exception, whereas members of the advocacy coalition fighting against the introduction of the second-pillar pension system (ČSSD, KSČM) were adamantly opposed. The discussion was conducted in the same argumentative spirit that accompanied previous ideological battles between advocacy coalitions. On the one hand, the financial instability of the system was raised as well as the need to strengthen merit, on the other hand there was a resounding defense of solidarity and concern about the weakening of the first pillar of the pension system. The "Devil shift" is also reflected in the sharp rhetoric used during the approval process.

The government submitted a draft bill on 30 June 2011. The first reading took place on 13 July 2011 . The second reading passed both a general and detailed debate on 30 August 2011. The third reading took place on 9 September 2011. The bill was approved. 86 out of 147 deputies present voted for the bill (ODS, TOP 09, VV, 1 independent member). 61 deputies were against the proposal (ČSSD, KSČM, 1 independent member). On 19 September 2011, the law was forwarded to the Senate. The Czech Senate rejected the bill. The vote was attended by 61 senators. 43 senators rejected the bill (36-CSSD, 5 - KDU-CSL, 2 independent members); 18 supported it (14 - ODS, 4 - TOP09 plus Party of Mayors).

The bill returned by the Senate was voted on, at the Chamber of Deputies on 3 and 6 November 2011. Deputies supported the original bill. 109 out of 179 deputies present voted for (ODS, TOP 09, VV, 1 independent member), 70 deputies were against (ČSSD, KSČM, 2 independent members).

The Act was delivered to the President for his signature on 9 November 2011. The President did not sign nor veto it, and therefore it became law on 24 November 2011 and came into force on 1 January 2013. 
The voting on the law in parliament only endorsed the composition of the two advocacy coalitions that were formed in the previous coordinative and communicative discourse.

In terms of resources of actors, we can consider the coalition promoting the second pillar of the Czech pension system as being dominant. Among its members were actors who were directly part of the executive branch of government or had access to other actors who were able to influence political decisions or possess information resources (government-coalition political parties, Ministry of Finance, Ministry of Labour and Social Affairs, government advisory bodies, pension funds, research institute IDEA-CERGE), which was formidable due to the previously mentioned type of players AC (coalition actors). The second AC, upon review of the resources of its actors, must be considered to be minor.

\subsection{Before the new general elections}

New extraordinary elections to the Chamber of Deputies happened at the end of 2013. To the forefront of the election debate came the measure to abolish the newly passed element of the pension system by all member of the advocacy coalition opposing the governmental decision. During the election, the platforms of ČSSD and KSČM explicitly expressed that, in case of electoral victory, they would seek its abolishment. Argumentative strategies were governed by the defense of solidarity as a key element in the compulsory public social insurance, which this newly introduced element of the system weakens, and the effort to maintain the sustainability of the first pillar of the pension system.

\subsection{After general elections - disintegration and transformation of advocacy coalitions}

The parliamentary elections in 2013 were won by the center-left Social Democrats (ČSSD) and they formed coalitions, which opened up opportunities to promote the objectives of the opinions of the close partners united in opposition to the introduction of the second pillar of the pension system. In the coalition agreement (ČSSD, newly-established political movement ANO, KDU-ČSL) and subsequently in the government's program declaration (2014), there occurred the explicit intention to create an expert commission to consider a further pension reform path and to advise how to end the second pillar (Vládní programové prohlášení 2014). Christian-democratic party KDU-ČSL became a new ally, joined the government's criticism of the second pillar of the pension system, which it deemed incapable of reform, and stood for its abolition. One surprising ally was a new entity, the political movement ANO. In their election program they did not dispute the existence of the second pillar, on the contrary, their aim was strengthening its robustness. In the end, ANO, however, agreed with the government's policy statement, in which the coalition partners' commitment to the abolition of the second-pillar pension account remained. 
After the election there arose a situation when the advocacy coalitions were hit by external (indirect) change. Clusters with significantly different political orientations took over power in the state. Some political parties "disappeared" from the arena of the key actors (e.g. VV - Public Affairs), while some had returned (KDUČSL). The old advocacy coalitions, formed substantially in the form of former rivals vs. the coalition of the former opposition crumbled. The advocacy coalition opposing the introduction of a second pillar gained, as its actor, the so-called "formal authority", possessing the right to make policy decisions. This change flipped the role of the formerly dominant minority coalition and thus paved the way for the fulfillment of one of its important goals.

On the basis of the coalition agreement and the government of the Czech Republic's policy statement, the Expert Committee for Pension Reform (the acronym $\mathrm{OK}$ ) was established in order to seek broad political consensus about the continuation of the pension reform. Key criteria which followed in the draft pension reform were defined as the ability of the system to ensure adequate and decent pensions, strengthening the principle of merit, settlement transfers between family and society and the long-term sustainability of the pension system (Poslání 2014). Although at the beginning of the meetings of $\mathrm{OK}$, which were concerned with the question of how to end the second pillar, there was a clash of former traditional advocacy coalitions regarding other activities of the Committee, when attention was focused on the broader concept of pension reform, there was an interesting shift. Former members of advocacy coalitions began looking for space to promote their interests in the new situation and to form new alliances. The attention of some members of the former government advocacy coalition had moved to the robust support for the third pillar (voluntary pension insurance/savings with state contribution, established as soon as in 1995).

On 23 October 2015, the Czech parliament passed a law abolishing the second pension pillar as of 2017 and strengthening the third pillar as of 2016.

\section{Discussion}

It seems to be obvious that the representation in the executive branch of government coalition is crucial in the battle of advocacy coalitions to orientate pension reform. Further, executive representation in the advocacy coalition increases the likelihood of enforcing the changes. If the government participated in the advocacy coalition, there is a likelihood of success, explicitly expressed by the enforcement of the concept which that particular advocacy coalition presents, and which has a higher probability of success than the coalition which does not have such representation. Within the framework of the dueling advocacy coalitions in the case of pension reform in the Czech Republic, the government and political parties were the key members of the advocacy coalition whose concept was enforced in the Czech Republic. 
On the contrary, the absence of the executive in an advocacy coalition can (knowing the impossibility of enforcing their own concepts) limit the activities of this coalition to attempt to block the implementation of the proposals of the opposing coalition. Nevertheless, the advocacy coalition opposing the introduction of the second pillar of the Czech pension system was focused not only on a "negative" campaign within the meaning of attempts to block its creation, but also on formulating alternative proposals for solutions. The advocacy coalition was not successful in an attempt to block the introduction of the second pillar until after the extraordinary parliamentary elections redistributed power, however.

Our analysis also focused on the uniformity of opinions within coalition. Both identified coalitions show unity and consensus among its members in the primary focus. In this case, the purpose is to perceive the introduction or failure to introduce (or cancel) the second pillar of the pension system. In the secondary aspect, however, we can already identify differences in opinion. In the first coalition, which advocated the introduction of a second pillar, the differences of opinion were already being expressed regarding the conception of the very nature of this institute, with respect to its construction. NERV, concurring with financial institutions, promoted compulsory participation as an essential parameter for the pillar to work effectively. By contrast, the government, certainly under internal political pressure, eventually pushed for the concept of voluntary participation. The second advocacy coalition was united in its negative stance toward the second pillar, whereas with the question of the "correct alternative concept of pension reform", the consensus was not achieved. Due to the variability of opinion of members of this coalition, a unified "opposition" counterproposal to pension reform was not advanced. Proposals for pension reform varied from complex concepts about pension reforms with the goal of sustainability of the system while maintaining a high degree of solidarity, to proposals for the introduction of the NDC system via adjustments that take into account, e.g., caring about children, to a "mere" parametric modification of the first pillar.

We also paid attention to the motivation of actors to become part of a coalition. We have already proved that some actors are motivated to be a member of a coalition in which they are a member of the executive government, mainly because of the higher probability of bringing about change. Thus this type of advocacy coalition is more attractive to actors (due to the higher potential to succeed). If the aim of the actors is to promote partial interest, then the ideological background may not necessarily be the only factor that determines membership in the coalition. The coalition which promoted the introduction of the second pillar of the Czech pension system lost its players who possessed executive and legislative powers. Discussions about the newly created platform Expert Committee on Pension Reform, established by the newly formed government of the Czech Republic after the early parliamentary elections in 2014, suggest a shift of "interests" of some actors. Financial institutions pragmatically abandoned support for the second pillar (after the 
decision on its dissolution), and strategically focused on advocacy towards the additional third pillar with respect to strengthening it. Based on this observation, we can confirm that the ideological kinship may not be the only factor that determines the membership of actors in AC. However, it is necessary to take into account the differences between the actors, in particular their ideological distinctiveness and their interests. The reasons for the actors to be involved in the activities of any coalition may be different. In some (such as political parties) coalitions play a key role in the ideological kinship with other actors. In others (such as private or public institutions) the ability/inability (individually or in a team advocacy coalition) to promote their vested interests plays an important role.

Advocacy coalitions' rivalry can also be the source of an additional flow of information relevant to political decision-making. It is the result of advocacy coalitions dueling with opposing views, which strengthens the argumentative strategies within them. We can trace the positive information effect resulting from the coordination argumentative strategy, even in the variants of the reform concepts presented by actors within one advocacy coalition. Joint activities (seminars, presentations, studies) were presented to the public as well as to the coalition partners by financial, research, and even educational institutions that were associated with the presentation and communication of reform options. There was a parallel increase in the interpretive approaches in the opposition coalition represented by the sharing and use of information between the traditional social partners (ČMKOS), the political parties on the left of the political spectrum and civic associations (CESTA). Information value is reflected in the treatment of the subject by political parties and, ultimately, in the final presentation of the topic by government executives. One of the most significant pieces of information shifts, which the conflict brings to the coalition, is the creative writing of the media (to increase their interest in the subject). This benefit may be weakened by special interest misinterpretations, the resulting biases and sometimes by unprofessional media messages covering factually complex themes like the pension system and its reform.

\section{Conclusion}

The Advocacy Coalition Framework proved functional in the explanation of situations where there were sharp political conflicts. Through the lens of the devil-shift of both camps (advocacy coalitions with different beliefs), each fell into extreme positions within the coalition to affirm the correctness of their arguments and positions. Shared beliefs, their own opinions and views became more entrenched, deepening the barrier between the coalitions, as well as solidifying the convictions of political opponents.

From an analytical point of view, the application of ACF was tied to a specific institutional form of political system, the actual distribution of political power 
and differentiated interests. If the institutional environment is set up in a way that does not necessarily require agreement across the political spectrum and within the broader framework of actors, ACF identified an unwillingness and inability to seek a compromise between competing advocacy coalitions. We were witnessing the adoption of sometimes extreme solutions, which were enforced by the current position of the actors in the political arena, and its radicalism has the potential for at least partial success, especially in an underdeveloped political culture of negotiation skills and preparedness to make compromises.

In situations where the actors are forced, whether by an institutional environment (political culture of negotiation and seeking compromise, tradition of tripartite agreements, etc.) and/or external influences (e.g. the results of elections) to negotiate at the "common table", ACF can be applied sparingly. In these conditions, it is interesting to see the regrouping of advocacy coalitions under the influence of the changing institutional conditions and the impact of these rearrangements, as well as the influence of marginal actors on the argumentative strategies and decisionmaking potential of the main actors. We still encounter the limits of the Advocacy Coalition Framework itself, since beliefs and views in such environments recede into the background and the actors begin to further promote their specific, differentiated interests.

\section{List of abbreviations}

ACF Advocacy Coalition Framework

ANO Ano bude líp (political movement)

CESTA Centre for Social Market Economy and Open Democracy

ČMKOS Czech-Moravian Confederation of Trade Unions

ČSSD Czech Social Democratic Party

KDU-ČSL Christian and Democratic Union - Czechoslovak People’s Party

KSČM Communist Party of Bohemia and Moravia

NDC Notional Defined Contribution pension system

NERV The National Economic Council, Czech Republic

ODS Civic Democratic Party

OK Expert Committee on Pension Reform, Czech Republic

PAYG Pay-as-you-go pension system

PES Expert Advisory Corps/Bezděk Second Commission

VV Public Affairs (political party) 


\section{Table}

Terminology of Pillars in the Czech Pension System

\begin{tabular}{|l|l|}
\hline First pillar & Public, defined-benefit, PAYG pillar \\
\hline Second pillar & $\begin{array}{l}\text { Voluntary private, defined-contribution, fully-funded pillar } \\
\text { (2013-2015) }\end{array}$ \\
\hline Third pillar & $\begin{array}{l}\text { Voluntary pension insurance with a state contribution (1994-2012), } \\
\text { voluntary savings with state contribution (since 2013) }\end{array}$ \\
\hline
\end{tabular}

\section{References}

Adámková, A. 2011 "Vládní návrh penzijní reformy je taková bramboračka." Interview with Jiř́ Rusnok. Parlament, vláda, samospráva [Parliament, government, local government]. Parol, s.r.o. Available at http://www.parlamentvlada.eu/index.php/rozhovor-finance/53-vladni-navrh-penzijni-reformy-jetakova-bramboraka (last accessed, October, 2015).

Bezděk, V., J. Münich, J. Procházka, J. Rusnok, P. Zahradník and M. Zámečník. 2011. "Důchodová reforma očima nervu" [Pension reform - NERV perspective]. Available at http://archiv.ihned.cz/c1-51131930-experti-z-nervu-duchodova-reforma-ocima-nervu (last accessed July, 2014).

Birkland, T. 2005. An Introduction to the Policy Process: Theories, Concepts, and Models of Public Policy-Making. $2^{\text {nd }}$ edn. Armonk: M. E. Sharpe.

CESTA. 2011a. "Návrh penzijní reformy (verze s NDC)" [Pension reform proposal (NDC version)]. Available at http://www.centrum-cesta.cz/files/prectete-si/ publikace/navrhy-penzijni-reformy-pro-ceskou-republiku/navrh-penzijnireformy-1-verze-s-NDC.pdf (last accessed August, 2014).

CESTA. 2011b. "Návrh penzijní reformy (verze se zohledněním výchovy dětí v průběžném systému)" [Pension reform proposal (a version taking into account the education of children in the PAYG system)]. Available at http:// www.centrum-cesta.cz/files/prectete-si/publikace/navrhy-penzijni-reformypro-ceskou-republiku/navrh-penzijni-reformy-2-verze-se-zohlednenim-deti-v-prubeznem-systemu.pdf (last accessed August, 2014).

ČMKOS. 2011. "Stanovisko Českomoravské konfederace odborových svazů $\mathrm{k}$ návrhům zákonů o důchodovém spoření” [Standpoint of the Czech-Moravian Confederation of Trade Unions toward the Law Propositions on Pension Insurance]. Available at http://www.cmkos.cz/data/articles/down_3085.pdf (last accessed 17 June 2011). 
ČSOB. 2012. "Státní důchody čeká strmý propad, vstup do II. piliứe se vyplatí téměř polovině populace" [State pensions will fall down sharply, nearly one half of the population will profit from entering the second pillar]. Available at http://www.csob.cz/cz/Csob/Servis-pro-media/Tiskove-zpravy/Stranky/ TZ120626.aspx (last accessed 26 June 2012).

ČSSD. 2011. "Programový dokument - Důchodová reforma ČSSD 2011" [Program Platform - Pension reform CSSD 2011]. Available at http://www.cssd.cz/ data/files/duchody-0004.pdf (last accessed 2015).

Kingdon, Robert M. 1994. "The Genevan Consistory in the time of Calvin." Calvinism in Europe, 1540-1620. Ed. Andrew Pettegree. New York: Cambridge University Press., 21-24.

Kohout, P. 2011. "Důchodová reforma se důsledně vyhýbá návrhům NERVu a Bezděkovy komise" [Pension reform consistently avoids the NERV and Bezděk commission proposals]. Available at http://www.nasepenize.cz/ pavel-kohout-duchodova-reforma-se-dusledne-vyhyba-navrhum-nervu-abezdekovy-komise-9300 (last accessed 1 July 2014).

Mintrom, M. and S. Vergari. 1996. "Advocacy Coalitions, Policy Entrepreneurs, and Policy Change." Policy Studies Journal 24, 420-435.

MPSV. 2010. “Závěrečná zpráva PES” [Final Report PES]. Available at http://www. mpsv.cz/files/clanky/8896/2010_06_03_Zaverecna_zprava_final_cistopis. pdf (last accessed October, 2015).

NERV. 2011. "Důchodová reforma" [Pension Reform]. Available at http://www.vlada.cz/assets/media-centrum/aktualne/NERV_Duchodova-reforma.pdf (last accessed October, 2015).

Poslání Odborné komise pro důchodovou reformu [Mission of the Expert Committee on pension Reform]. 2014. Available at http://www.duchodova-komise. $\mathrm{cz} /$ ?page_id=47 (last accessed October, 2015).

Potůček, M. and V. Rudolfová. 2015 "Czech Pension Reform: How to Reconcile Equivalence with Fiscal Discipline." Central European Journal of Public Policy 9(1), 170-195. Available at http://www.cejpp.eu/index.php/ojs/article/ view/226/142 (last accessed December, 2015).

Quattrone, G. A. and A. Tversky. 1998. "Contrasting Rational and Psychological Analyses of Political Choice." American Politicial Science Review 82(3), 719-736.

Sabatier, P. and Ch. Weible. 2007. "The Advocacy Coalition Framework: Innovations and Clarifications." In Paul Sabatier (ed.). Theories of the Policy Process. $2^{\text {nd }}$ edn. Boulder: Westview Press, 189-222. 
Tyden.cz. 2011. “Člen NERV Zámečník se distancuje od penzijní reformy” [NERV’s Member Zámečník Dissociates himself from Pension Reform]. Available at http://www.tyden.cz/rubriky/byznys/cesko/clen-nerv-zamecnik-se-distancuje-od-penzijni-reformy_195447.html?showTab=kurzovni-listek\#.VMk3ncb8EZk (last accessed October, 2015).

Vládní programové prohlášení [The government's policy statement]. 2014. Available at http://www.vlada.cz/cz/media-centrum/dulezite-dokumenty/programove-prohlaseni-vlady-cr-115911/ (last accessed 14 February 2014).

Weible, Ch. and D. Nohrstedt. 2013. "The Advocacy Coalition Framework: Coalitions, Learning and Policy Change." In E. Araral Jr., S. Fritzen, M. Howlett, M. Ramesh and X. Wu (eds). Routledge Handbook of Public Policy. Abingdon (New York): Routledge, 125-137.

Weible, Ch., P. Sabatier, H. Jenkins-Smith, D. Nohrstedt and A.D. Henry. 2011. "A Quarter Century of the Advocacy Coalition Framework: An Introduction to the Special Issue." Policy Studies Journal 39(3), 349-360. 